\title{
Mass mortality of cultured ascidians Halocynthia roretzi associated with softening of the tunic and flagellate-like cells
}

\author{
Akira Kumagai ${ }^{1, *}$, Atsushi Suto ${ }^{1}$, Hiroshi Ito ${ }^{1}$, Toru Tanabe $^{1}$, Kiyotaka Takahashi $^{1}$, \\ Takashi Kamaishi ${ }^{2}$, Satoshi Miwa ${ }^{3}$ \\ ${ }^{1}$ Miyagi Prefecture Fisheries Technology Institute, Ishinomaki, Miyagi 986-2135, Japan \\ ${ }^{2}$ National Research Institute of Aquaculture, Fisheries Research Agency, Minami-ise, Mie 516-0193, Japan \\ ${ }^{3}$ Inland Station, National Research Institute of Aquaculture, Fisheries Research Agency, Tamaki, Mie 519-0423, Japan
}

\begin{abstract}
Since 2007, mass mortalities of cultured ascidians Halocynthia roretzi (Drasche) have occurred in Miyagi Prefecture, Japan. The mortalities occur from November through August, and the tunics of affected animals become abnormally weak and soft. The number of farming areas where mass mortalities have occurred has increased rapidly: 3 in 2007, 6 in 2008, and 14 in 2009. When an outbreak of the disease occurred, mortality reached 17 to $100 \%$. Prominent histopathological changes in the diseased ascidians were found in the tunics; the tunics of affected animals were usually much thinner than those of healthy individuals, and the tunic matrix showed marked disintegration with irregular arrangements of fiber layers or the presence of hollow spaces. In addition, flagellate-like cells $(10-14 \mu \mathrm{m} \times 2-3 \mu \mathrm{m})$ stained with hematoxylin were observed in the tunics of 31 out of 36 diseased animals $(86 \%)$, but not in apparently healthy animals $(\mathrm{n}=38)$. Experimental infection with the disease was successfully conducted by immersing small pieces of tunic samples from diseased ascidians into aquaria with healthy ascidians. The flagellate-like cells were confirmed in the tunics of all the experimentally infected animals. These results indicate that the mass mortalities of ascidians accompanied by abnormally softened tunics were caused by an infectious agent, and suggest the involvement of the flagellate-like cells in the disease.
\end{abstract}

KEY WORDS: Ascidian - Halocynthia roretzi - Mass mortality $\cdot$ Soft tunic syndrome $\cdot$ Etiology · Flagellate

Resale or republication not permitted without written consent of the publisher

\section{INTRODUCTION}

The edible ascidian Halocynthia roretzi, also called 'sea pineapple', is a popular seafood in the northern part of Japan and Korea. In Japan, aquaculture of the ascidians started in the 1900s in Miyagi Prefecture, along the Pacific coast of the northern part of Japan's main island, Honshu, and it is now an important aquaculture species in the region. The annual production of the cultured ascidians was approximately 10000 tons in 2006 in Japan, with nearly $85 \%$ being cultured in Miyagi Prefecture. For culturing, spat (young animals that have just settled on a substrate) are collected from December to January on oyster shells that are suspended close to farming sites of adult ascidians, and are then cultivated there until the next July to November. Thereafter, the shells with spat that have grown to 2 to $10 \mathrm{~mm}$ are attached to ropes (20 m in length) at intervals of 0.5 to $0.8 \mathrm{~m}$. The ropes are then brought to farming sites and hung vertically to allow the ascidians to grow. Water temperature ranges from 8 to $22^{\circ} \mathrm{C}$ annually in most of the farming areas. After cultivation for 3 to $4 \mathrm{yr}$, the ascidians, which have usually grown to 200 to $300 \mathrm{~g}$ body weight, are harvested.

In Korea, mass mortalities from a disease of unknown etiology have been a serious problem in the cultured ascidians of all age groups since 1995 (Jung et al. 2001). The tunics of affected ascidians are physically very soft and weak. This is conspicuous, since the tunic, the outer covering of Halocynthia roretzi, is nor- 
mally very hard and stiff, and usually remains so even after death of the animal. The disease accordingly has been called 'tunic softness syndrome' (Hur et al. 2006) or 'soft tunic syndrome' (Hirose et al. 2009). Because of outbreaks of the disease, annual production of the farmed ascidians in Korea decreased from 42800 tons in 1994 to 4500 tons in 2004. To fulfill the demand for the ascidians, a large amount of cultured ascidians has been exported from Japan to Korea since 2002. The production of ascidians and the number of ascidian farms has increased accordingly in Miyagi Prefecture, resulting in a shortage of domestic spat for culture. Although the local government of the prefecture had warned ascidian farmers about the disease outbreaks in Korea, some farmers imported spat from Korea in 2004 and 2006.

In February 2007, disease outbreaks occurred in cultured ascidians in Miyagi Prefecture, in the areas where Korean spat had been introduced. Tunics of the affected animals were markedly softened, suggesting the soft tunic syndrome. All the farmed ascidians at the sites where the disease occurred were destroyed. However, the disease has been re-occurring every year, and the number of affected areas has been increasing. The economic loss from the disease is substantial, and hence, identification of the cause of the disease is urgently needed to control the epizootic.

Although investigations have been conducted on the soft tunic syndrome in Korea, the cause of the disease is still unknown (Jung et al. 2001, Choi et al. 2006, Azumi et al. 2007a,b). Because experimental infections of the disease have not been carried out, it is still uncertain whether the disease is infectious or not. In the present study, occurrences of the disease were monitored in the farming sites in Miyagi Prefecture from 2007 to 2009. Additionally, we confirmed that the disease is transmissible by experimental infections. We also conducted a histopathological study and found flagellate-like cells specifically in the tunics of affected animals. To clarify whether the cells are ascidian cells or protists, in situ hybridization (ISH) was carried out using probes for the ascidian $18 \mathrm{~S}$ ribosomal RNA (rRNA) gene.

\section{MATERIALS AND METHODS}

Epizootiology. To monitor the occurrence of the disease, 20 farming sites (Stns 1 to 20 in Fig. 1) were selected. At each farming site, 5 to 20 vertical ropes were randomly chosen at each monitoring time, and 500 to 3000 individuals were examined for the disease by touching the tunic. When ascidians with softened tunics were found, some of them were sampled for histopathological examinations and infection trials. The observations were conducted in February 2007

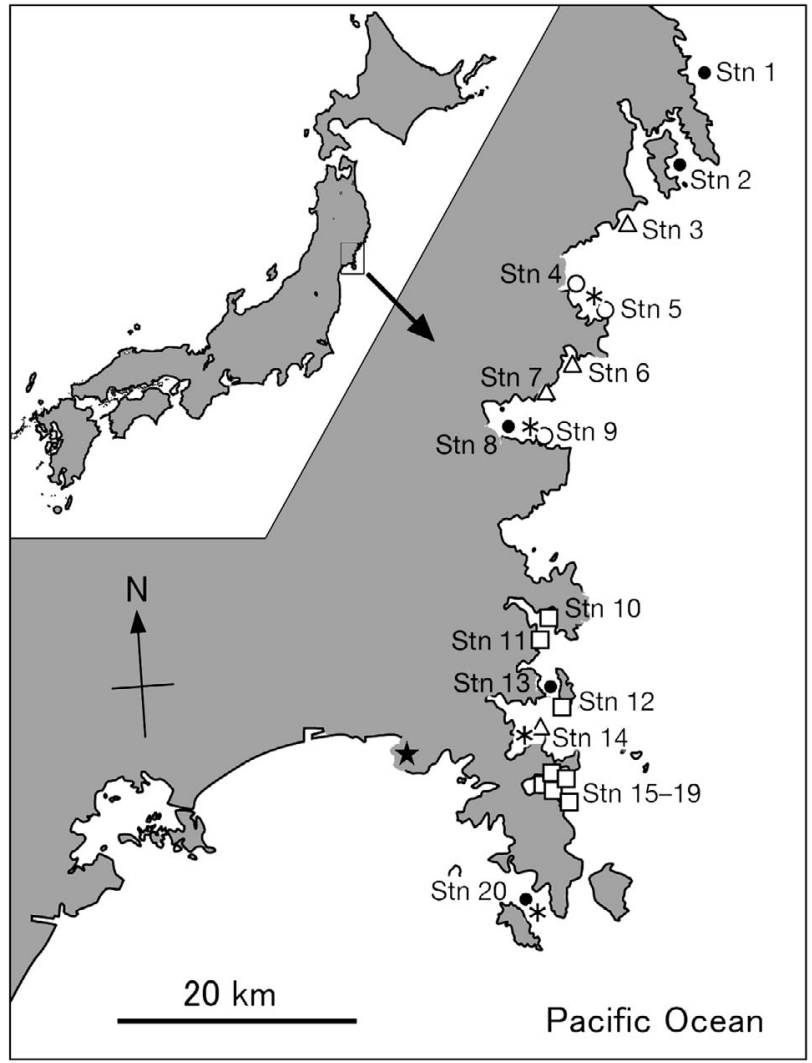

Fig. 1. Locations of 20 monitoring stations along the coast of Miyagi Prefecture, Japan. *: areas where ascidians were introduced from Korea in 2004 and/or 2006. Symbols represent

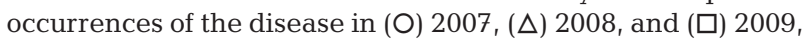
and $(\bullet)$ no occurrence, respectively. Once the disease occurred, the disease most often recurred at the same station in the following years. $\star$ : location of Miyagi Prefecture Fisheries Technology Institute, where the experimental infections were conducted

and monthly from January to August 2008 and from February to July 2009. We also made inquiries to the ascidian farmers in those areas about the history of the introduction of ascidians from other areas.

To track the disease spreading among nearby individuals, 6 culture ropes, on which the ascidians were suspended, were marked at Stn 14, where the disease had occurred. The 6 ropes comprised 3 ropes of 3 yr old $(2+)$ animals and 3 ropes of 2 yr old (1+) animals. Three yr old animals (approx. $\mathrm{n}=200 \mathrm{rope}^{-1}$ ) and $2 \mathrm{yr}$ old animals (approx. $n=250$ rope $^{-1}$ ) that were attached to the top quarter of the culture rope were examined monthly for mortality from the disease, from May 2008 to August 2009. The ascidians are usually cultured at depths from 5 to $20 \mathrm{~m}$ from the surface, and the water temperatures and salinities at depths of 1, 5, 10, 15, and $20 \mathrm{~m}$ were measured monthly using a salinity-temperature-depth profiler (AST500-PK, Aleck Electronics) at Stn 14. 
In addition, the following groups were also monitored in the same way from April to October in 2008: 1 rope with 3 yr old ascidians containing diseased animals with softened tunics at Stn 6, 2 ropes with 3 yr old animals containing diseased animals with softened tunics at Stn 7, and 1 rope with apparently healthy 3 yr old animals at Stn 2, where the disease has previously not been found.

Histopathological examination. Diseased ascidians ( $n=36$ ) comprising 32 animals with apparently softened tunics and 4 animals with mildly softened tunics were sampled from March 2007 to August 2008 at Stns 5, 6, 7, 9, and 14. For comparison, moribund or abnormal individuals $(\mathrm{n}=8$ ) that were thought to be affected by factors other than the soft tunic syndrome were sampled in August 2008. These samples included animals that had deteriorated appendages for attachment to the substrate and animals whose tunics were, although still hard, discolored and lacking elasticity. In some of these samples, the tunics had become detached spontaneously from the underlying soft tissues. These clinical signs were not observed in the ascidians putatively affected by soft tunic syndrome. Apparently healthy individuals $(\mathrm{n}=38)$ were also sampled from June 2007 to July 2008 at Stns 1, 2, 5, 10, and 13. For early samples ( 9 specimens among the 36 diseased ascidians and 18 specimens among the 38 healthy ascidians), pieces of the tunic, digestive cecum, gill, muscle, and gonad were removed from each animal and fixed in Davidson's fixative (Bell \& Lightner 1988) overnight, except for 1 specimen sampled in March 2007, which was fixed in $10 \%$ formalin. Two or more tunic pieces were cut out from different parts of the tunic for histopathological examination. For the other, later samples, only the pieces of tunics with the underlying soft tissues were used for histology. After fixation, tissues were routinely dehydrated with ethanol and embedded in paraffin. Two sets of sections were cut at $3 \mu \mathrm{m}$ and stained with either Mayer's hematoxylin and eosin (H\&E) or May-Grünwald and Giemsa (M\&G).
Additionally, the tunics of diseased $(n=4)$ and healthy $(n=1)$ ascidians fixed in $10 \%$ formalin were also used for histological observations. These animals were sampled at a farming site in Korea in April 2009 and generously provided by Prof. Jung Tae Sung, Gyeongsang National University, Korea.

Probes for ISH. To clarify whether flagellate-like cells found in the affected tunics were a type of ascidian or a parasitic organism, ISH was conducted using probes for the 18S rRNA gene of the ascidian.

Five oligonucleotide probes complementary to variable regions of the 18S rRNA gene of Halocynthia roretzi (GenBank accession number AB013016) were synthesized so that they would hybridize with the $18 \mathrm{~S}$ rRNA in the cytoplasm (Table 1). An additional 3 oligonucleotide probes for a fish-parasitic protist (Miwa \& Kamaishi 2009) were used as the negative control (Table 1). Probes were labeled with digoxigenin, using a commercial kit (DIG Oligonucleotide Tailing Kit, Roche) according to the manufacturer's instructions.

ISH. Diseased tunics of 3 individuals were used for ISH. One animal was sampled in April 2008 at Stn 6. The other 2 were newly sampled at Stns 17 and 18 respectively in May 2009. ISH was carried out according to the method described previously (Miwa et al. 2004). The 5 probes for the ascidian gene were used in combination to intensify the hybridization signal. The 3 probes for the negative control were also used in combination. The final hybridization solutions were prepared so that the nominal total concentrations for both probe combinations would be the same. For each specimen, 2 sets of $3 \mu \mathrm{m}$ sections were prepared. One of them was subjected to ISH and the other was stained with $H \& E$ to determine the localization of the clusters of flagellate-like cells.

Infection tests. The presence of an infectious agent was tested in the following 4 experiments. Two yr old, healthy ascidians of 150 to $190 \mathrm{~g}$ body weight were obtained from Stn 10 or 12, where the disease had not

Table 1. Probes synthesized for in situ hybridization

\begin{tabular}{|c|c|}
\hline Probe & Sequence \\
\hline \multicolumn{2}{|c|}{ Probes for 18S rRNA of Halocynthia roretzi } \\
\hline Maboya-200r & 5'-GGT CGG TTT TGA TCT GAT AAA AGC ACG CCT CCC GGA GTC GGC GCT TAC GC-3' \\
\hline Maboya-280r & 5'-ACT TGA ATG ATT CGT CGT CGG TAC AGA GAC CAT ACG ATC CGC GTG GTT AT-3' \\
\hline Maboya-680r & 5'-AAC CGA AGG CGA GGC GAG CGC AGC CAG TGC ACG CCT TGC GAC GGA CCG GC-3' \\
\hline Maboya-1500r & 5'-GGT TAC CCG GAC CTT TCG GCC TAG GGC ATT CAC TCG CTG ATC CAT TCA GT-3' \\
\hline Maboya-1710r & 5'-TCT TCT CGG CTC GCC GCC GCG GCC GTT GCC GAC CGC GAA GGG GCC AAT CC-3' \\
\hline \multicolumn{2}{|c|}{ Probes for 18S rRNA of X-cell organisms from yellowfin goby } \\
\hline HXC-217r & 5'-CAG AAC CGT GTT GAT CTG ATA ATA AGG TCT TCA TTC GCA GAA GAA ACA TG-3' \\
\hline $\mathrm{HXC}-1376 \mathrm{r}$ & 5'-AAG TTG TAG ACC GAA TGT ACA GAG GGA GGT CTT ATC CCC TGA GAG AAC AG-3' \\
\hline HXC-1696r & 5'-CGA TTC ACC AGT TCA GGC GAG TCT CTA CTG AGC TTA CCG GAT CAT CCA AT-3' \\
\hline
\end{tabular}


been observed. The infection tests and the characterization of some physical properties of the causative agent described in the next section ('Physical characteristics of the putative causative agent') were carried out at Miyagi Prefecture Fisheries Technology Institute. Seawater used for these experiments was pumped from offshore of the laboratory and filtered through a sand filter before flowing into the experimental aquaria. Each experimental aquarium was aerated.

Expt 1: Hemolymph from a diseased ascidian with a softened tunic obtained from Stn 5 was injected $(0.1 \%$ of body weight) into 5 healthy ascidians beneath the tunic. The injected animals were reared in a 401 aquarium filled with running seawater. Hemolymph from a healthy ascidian was also injected into another 5 healthy animals as controls and the control animals were reared similarly in another $40 \mathrm{l}$ aquarium.

Expt 2: Twelve healthy ascidians were reared together with 4 diseased animals with softened tunics from Stn 5 in a 251 aquarium filled with 201 of running seawater. For the control, another 12 healthy ascidians were similarly reared with 4 healthy animals from Stn 10. All the ascidians used as the source of inoculum died within $7 \mathrm{~d}$ after the start of the experiment, and were removed from the aquarium when they were found to be dead.

Expt 3: The tunics of diseased ascidians ( $\mathrm{n}=3$ to 5, 20 to $50 \mathrm{~g}$ in total) were cut into small pieces (approximately $5 \mathrm{~cm} \times 1 \mathrm{~cm}$ ), put into a polyethylene net (mesh size $7.5 \mathrm{~mm} \times 7.5 \mathrm{~mm}$ ) and suspended in a $25 \mathrm{l}$ aquarium containing 12 healthy ascidians for $5 \mathrm{~d}$. The aquarium was filled with $20 \mathrm{l}$ of running seawater. For the control, the tunics of healthy ascidians were similarly treated and suspended in an aquarium containing another 12 healthy animals. The experiment was repeated 6 times, using the tunics of diseased ascidians from different monitoring stations as the sources of inoculum. In the experiment using diseased ascidians from Stn 6, the tunics of ascidians $(n=5)$ that were considered to be infected with soft tunic syndrome during the experiment were provided for histopathological examination.

Expt 4: Two infection trials similar to those in Expt 3 were conducted, using diseased tunics $\left(\mathrm{n}=4 \mathrm{trial}^{-1}\right)$ of experimentally infected ascidians obtained newly from Expt 3.

Expts 1 to 4 were conducted until $60 \mathrm{~d}$ after the start of the experiment, and the softening of the tunics was monitored by touching the ascidians every $2 \mathrm{~d}$.

Physical characteristics of the putative causative agent. The following experiments tested the infectivity of the agent after 3 treatments.

Expt 5: Susceptibility to freezing: Softened tunics (100 $\mathrm{g}$ in total) of spontaneously infected ascidians ( $\mathrm{n}=$ 5) were cut into small pieces $(5 \mathrm{~cm} \times 1 \mathrm{~cm})$, pooled, and divided into 2 halves. One group was stored at $-80^{\circ} \mathrm{C}$ for $24 \mathrm{~h}$, put into a polyethylene net (mesh size $7.5 \mathrm{~mm}$ $\times 7.5 \mathrm{~mm}$ ), and suspended in a 251 aquarium containing 12 healthy ascidians for $5 \mathrm{~d}$. The other group was immediately suspended, without freezing, in a 251 aquarium also containing 12 healthy ascidians for $5 \mathrm{~d}$. Control groups were treated in the same way using the tunics of healthy ascidians from a population in which the disease had not been observed.

Expt 6: Susceptibility to physical damage: Softened tunics (20 $\mathrm{g}$ in total) of spontaneously infected ascidians ( $\mathrm{n}=2$ to 4 ) were cut into squares of $1 \times 1 \mathrm{~cm}$, pooled, and divided into 2 halves. One of them was minced on ice for $5 \mathrm{~min}$ by using a food processor (BMFX08, Zojirushi), put into a polyethylene net (mesh size $1 \mathrm{~mm}$ ), and suspended in a $25 \mathrm{l}$ aquarium containing 12 healthy ascidians. The other half was similarly used as the source of inoculum without mincing. Tunics $(10 \mathrm{~g}$ in total) of healthy ascidians $(\mathrm{n}=2)$ were similarly minced and suspended in a 251 aquarium containing 12 healthy ascidians as the control. These treatments were repeated once a day for $3 \mathrm{~d}$, so that each aquarium had 3 nets on the 3rd day of the experiment. All 3 nets were removed from each aquarium $5 \mathrm{~d}$ after the start of the experiment.

Expt 7: Size-fractionation: Softened tunics of infected ascidians $(\mathrm{n}=2)$ were cut into small pieces $(5 \times$ $1 \mathrm{~cm}$ ), pooled (20 to $40 \mathrm{~g}$ in total), and immersed in $300 \mathrm{ml}$ sterilized seawater at $15^{\circ} \mathrm{C}$ for $4 \mathrm{~h}$. Thereafter, the seawater supposedly containing the infectious agent was divided into 6 aliquots of $50 \mathrm{ml}$. Two aliquots were filtered through $5.0 \mu \mathrm{m}$ membrane filters. Another 2 aliquots were filtered through $0.45 \mu \mathrm{m}$ membrane filters. The remaining 2 aliquots were used without filtering. Subsequently, each aliquot was added to a 251 aquarium containing 12 healthy ascidians. The pieces of tunic were immersed again in $300 \mathrm{ml}$ of sterilized seawater at $15^{\circ} \mathrm{C}$ for $4 \mathrm{~h}$ and the seawater was similarly treated. The resultant filtrates or non-filtered aliquots were added to the corresponding aquaria in addition to the previous aliquots. Subsequently, the used tunics were immersed again in $300 \mathrm{ml}$ of sterilized seawater for $16 \mathrm{~h}$, and the seawater was similarly treated. Thus, 1 experimental aquarium was given 3 aliquots of $50 \mathrm{ml}$ in $24 \mathrm{~h}$. The whole procedure was repeated, using new tunics from diseased ascidians, every day for $5 \mathrm{~d}$. The pieces of diseased tunics after being immersed in seawater for $24 \mathrm{~h}$ in total were put into nets and suspended in 2 aquaria containing 12 healthy ascidians each to confirm that these tunics contained the pathogen. For these 2 groups, suspension of the tunics was conducted accordingly from the 2nd day to the 6th day of the experiment, and the suspended tunic pieces were replaced by new ones every day. Furthermore, pieces 
of tunics from healthy animals $(n=2)$ were suspended in an aquarium containing 12 healthy ascidians for the first $5 \mathrm{~d}$ of the experiment. For this group, the suspended tunic pieces were also replaced by new ones every day. In this experiment, ascidians in each aquarium were reared in aerated, still seawater. The seawater was not changed for the first $6 \mathrm{~d}$ of the experiment, so that the animals would be exposed to as much of the infectious agent as possible. After this period, the ascidians were reared in running seawater as in the other experiments.

Expts 5 to 7 were conducted until $60 \mathrm{~d}$ after the start of the experiment, and the softening of the tunics was monitored by touching the ascidians every $2 \mathrm{~d}$.

\section{RESULTS}

\section{Epizootiology}

The results of the disease monitoring are summarized in Fig. 1. The mass mortalities of the ascidians accompanied by markedly soft tunics were observed at 3 sites (Stns 4, 5, and 9) in 2007, 6 sites (Stns 3, 5, 6, 7, 9, and 14) in 2008, and 14 sites (Stns 4, 5, 6, 7, 9, 10, 11, $12,14,15,16,17,18$, and 19) in 2009. The affected ascidians were mainly $2+$ and $3+$ individuals and a small number of $1+$ animals, but no $0+$ ones. The outbreak of the disease usually occurred in $2+$ individuals for the first time at these sites and then recurred in the next year both in the surviving animals and small numbers of 1+ animals in the same areas. Among individual ascidians, the disease tended to spread sequentially from diseased animals to neighboring ones.

Epizootiological information from the inquiries to ascidian farmers revealed that 4 sites (Stns 4, 9, 14, and 20) had a previous history of ascidian introduction from Korea in summer 2004 and/or 2006, and these animals died or were destroyed within $1 \mathrm{yr}$ after being imported, regardless of the occurrence of the disease. Among 7 monitoring areas where the outbreaks of the disease occurred in 2007 and 2008, 3 had a history of introduction of ascidians from Korea and the other 4 are located close to these areas (Fig. 1).

In the observations of marked culture ropes, the disease sequentially spread from affected ascidians to neighboring individuals. The cumulative mortalities of $2+$ animals with weak tunics on the 3 marked ropes at Stn 14 increased rapidly until August 2008. The high mortality from the disease had subsided by September, when water temperatures often exceeded $20^{\circ} \mathrm{C}$ (Fig. 2A). The monitoring of 2 of 3 ropes of $2+$ animals was stopped in February 2008 when all animals of the groups had died. In the remaining group of $2+$ animals, the disease recurred from May to July 2009. In the 3
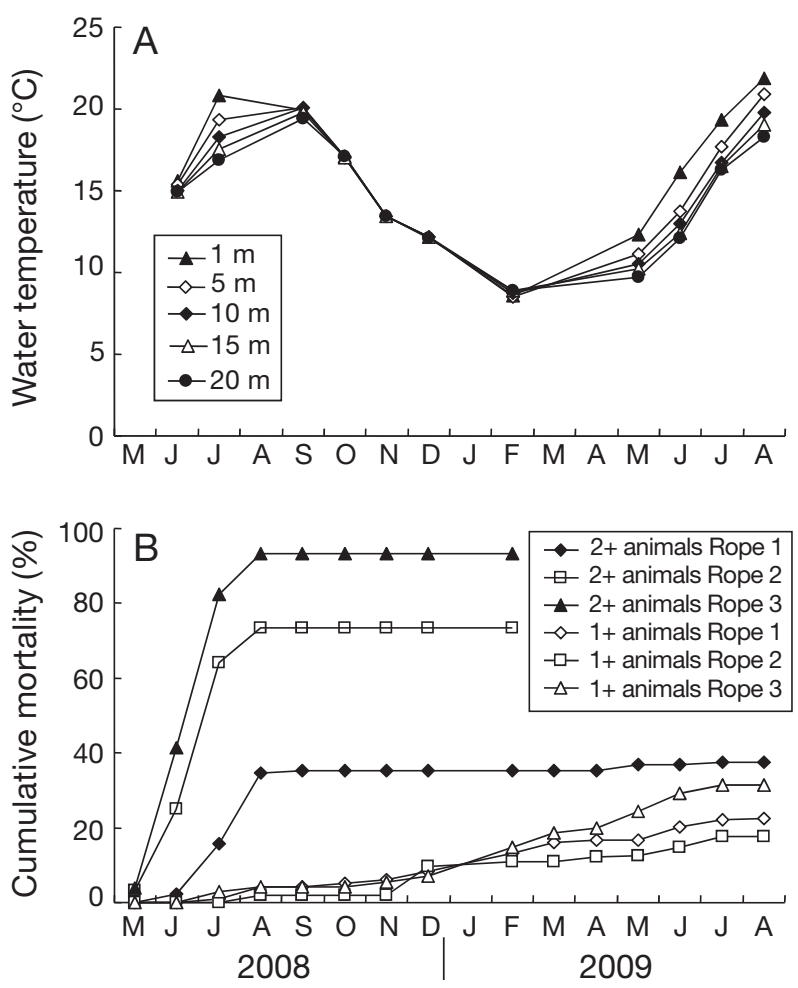

Fig. 2. Halocynthia roretzi. (A) Average water temperature and (B) cumulative mortalities of farmed ascidians with soft tunic syndrome attached to 6 culture ropes at Stn 14 from 2008 to 2009. Ascidians with apparently soft tunics were observed on $2+$ animals of Ropes 2 and 3 at the start of monitoring, but not on $2+$ animals of Rope 1 and all $1+$ animals. No mortality of 2+ groups from October 2008 to April 2009 was associated with abnormally soft tunics. The graph does not show the mortality due to factors other than softened tunics. Monitoring of 2 groups ended in February 2009 when all animals on these ropes had died. Note that the mortality of $2+$ animals of Rope 1 increased slightly from May to July 2009

marked groups of 1+ animals at Stn 14, the disease first occurred in July or August 2008 and then ceased by September. Subsequently, the disease recurred in October or November and lasted until August 2009 (Fig. 2B). Salinity measured at Stn 14 ranged from 31.5 to 33.9 at depths from 1 to $20 \mathrm{~m}$ during the monitoring period, and we did not find any particular changes in mortality associated with the changes in salinity. At Stns 6 and 7, the cumulative mortality of the 2+ animals with softened tunics on 1 marked rope at each station rose rapidly, and the observations of these groups were stopped in August when all the animals had died. The animals on the other rope at Stn 6 also showed high mortality until August, after which no ascidian with softened tunic was observed until October. No dead ascidian was found in the group at Stn 2 (Fig. 3) throughout the monitoring period. 


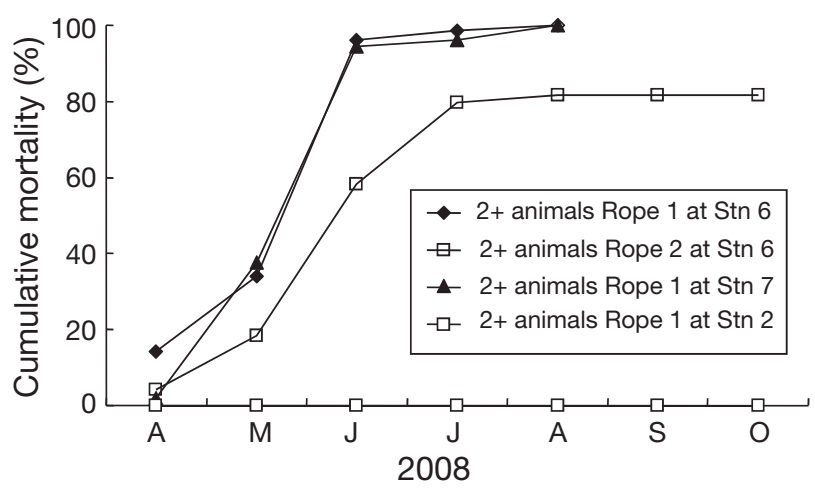

Fig. 3. Halocynthia roretzi. Cumulative mortalities due to soft tunic syndrome of farmed ascidians attached to 4 culture ropes at Stns 2, 6, and 7 in 2008. Ascidians with apparently soft tunics were observed on Ropes 1 and 2 at Stn 6, and on Rope 1 at Stn 7, but not on Rope 1 at Stn 2 at the start of monitoring. The graph does not show mortality due to factors other than softened tunics. Monitoring of 2 groups ended in August 2008 when all animals on these ropes had died

\section{Clinical signs}

The tunic of a healthy ascidian is usually very hard and it is difficult to make incisions using scissors in the tunic. For the diseased ascidians that were presumably affected by soft tunic syndrome, however, the tunics were much weaker and thinner than those of apparently healthy individuals (Fig. 4), and the tunics of the affected animals can be easily cut with scissors. In severe cases, the tunics were sometimes found to be torn open spontaneously. On the other hand, although the whole body of an affected animal was usually reduced in size as shown in Fig. 4, no other clinical signs were found in the internal organs of affected animals.

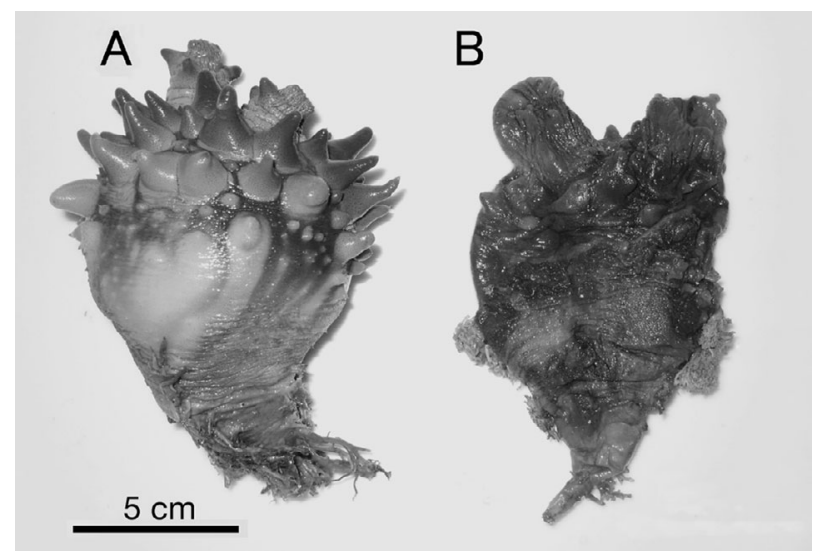

Fig. 4. Halocynthia roretzi. Gross view of (A) a healthy and (B) a diseased ascidian collected from a farming site in Japan

\section{Histopathology}

In histology, the tunic matrix of healthy individuals consisted of regularly arranged layers of densely packed tunic fibers (Fig. 5A), and not many cells were seen. On the other hand, the layers of the fibers of softened tunics were usually greatly disturbed, exhibiting inconsistency of the layers. In severely affected individuals, there were lesions where tunic fibers became very sparse, having hollow spaces within the matrix (Fig. 5B). Many dead or live cells and putative dead cell debris were often observed in softened tunics. In many cases, the tunic epidermis of the diseased animals seemed rather intact. In some severe cases, however, degenerated or dead cells were observed in the epidermis. Presumably degenerated or dead epidermal cells shed from the epidermis were sometimes found in the tunic matrix (Fig. 5C,D).

A conspicuous type of cells was observed in the softened tunics of the affected animals (Fig. 5E,F). The size of these cells was about 10 to $14 \mu \mathrm{m}$ along the long axis and 2 to $3 \mu \mathrm{m}$ along the short axis, although they seemed to be capable of flexibly changing their shape (Fig. 5F). These cells stained rather intensely with hematoxylin, and had polarity with a flagellum-like structure on one end. Each of these cells had a nucleus containing an eosinophilic nucleolus. The nucleus was smaller than those of other cell types found in the tunic, and difficult to observe at lower magnifications. These flagellate-like cells were found in 30 out of 32 animals with apparently softened tunics (94\%), and in 1 of 4 mildly affected animals $(25 \%)$. The cells were observed only in the matrix of the tunics, and were not found in the internal tissues or in the tunic epidermis. The flagellate-like cells were often observed in hollow spaces or in disturbed tunic fibers, although sometimes there were no such cells in those abnormal fiber layers. The localization of the flagellate-like cells was very uneven; in some instances, many flagellate-like cells were observed in a piece of the tunic whereas no flagellate-like cell was found in another piece dissected out from the same individual.

In severely affected animals, clusters of large numbers of hemocytes were often observed, particularly in the connective tissue layer beneath the tunic epidermis. In some cases, the clusters of hemocytes were formed in the basal area of the tunic. Among the hemocytes, there were strongly eosinophilic cells, which had large intracellular granules of varying sizes, showing marked resemblance to the cells that were reported to be infected with a paramyxian parasite by Choi et al. (2006). These eosinophilic hemocytes were, however, found in all ascidians observed, including apparently healthy animals. No other histopathological changes were observed in the internal organs. In 2 of the mori- 


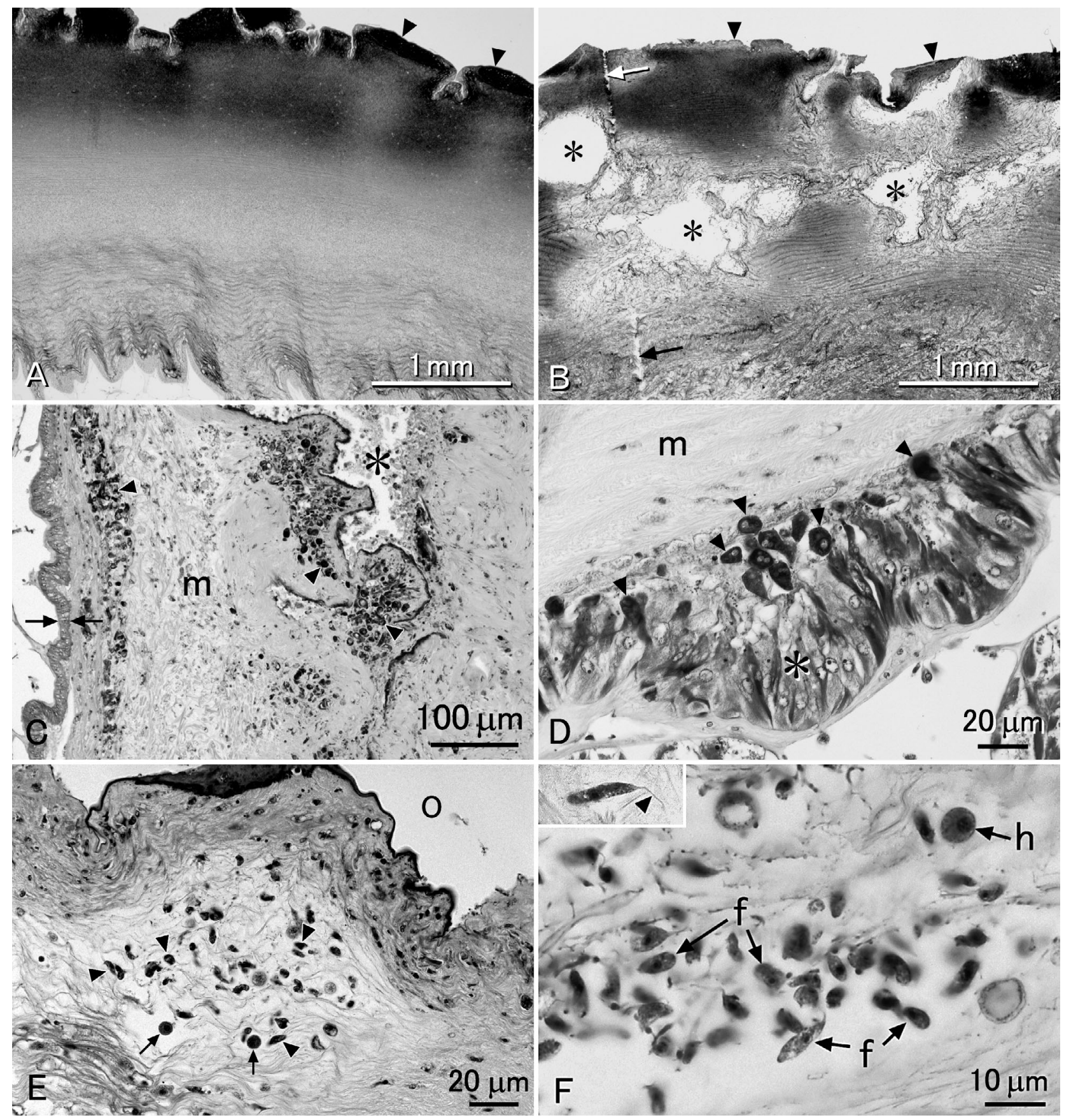

Fig. 5. Halocynthia roretzi. Histopathological sections of diseased and healthy ascidians. (A) Tunic of a healthy individual. MayGrünwald and Giemsa (M\&G) stain. Arrowheads indicate outer surface of the tunic. (B) Tunic of a diseased individual. The arrangement of tunic fibers is markedly disturbed and hollow spaces (*) have developed. Arrowheads indicate outer surface of the tunic. Arrows show a knife mark (an artefact). M\&G stain. (C) Tunic of a severely affected animal. Discontinuity of the tunic fibers and a large hollow space with cells and cell debris $(*)$ are apparent. In addition to many cells in the tunic matrix (m), clusters of deeply stained, presumably dead cells are observed (arrowheads). These cells are considered to be dead epidermal cells shed from the tunic epidermis (arrows), which seems normal in this picture. Hematoxylin and eosin (H\&E) stain. (D) Tunic epidermis (*) of an affected animal, probably exhibiting the shedding of dead epidermal cells (arrowheads) into the tunic matrix (m). The cytoplasm of some epidermal cells is condensed and likely to be degenerated. H\&E stain. (E) Flagellate-like cells (arrowheads) in the tunic of a diseased ascidian. Arrows indicate ascidian cells. O: outside the tunic. H\&E stain. (F) The flagellate-like cells at a higher magnification. Arrowhead indicates flagellum-like structure. Note the difference in the morphology of the nuclei of flagellate-like cells (f) and the ascidian cell (h). H\&E stain 
bund or abnormal ascidians $(\mathrm{n}=8)$ with rather normal, stiff tunics, flagellate-like cells were also found in the tunic matrix. However, these cells were much longer (>20 $\mu \mathrm{m}$ along the long axis and 2 to $3 \mu \mathrm{m}$ along the short axis) and apparently distinct from the flagellatelike cells found in the animals presumably affected by soft tunic syndrome. In another 3 individuals among these 8 animals, many cells in the tunic epidermis exhibited vacuolar degeneration and the fiber layers were often disturbed to varying degrees. The tunics of the other 3 animals were almost normal.

In the apparently healthy individuals $(\mathrm{n}=38)$, neither flagellate-like cells nor any other histopathological changes were observed.

Histopathological characteristics of the Korean samples were almost the same as those of the Japanese samples. The flagellate-like cells similar to those found in the Japanese samples were found in all 4 affected tunics, but not in the healthy tunic (Fig. 6).

\section{ISH}

The flagellate-like cells were not labeled with the probes for the ascidian 18S rRNA gene, whereas strong hybridization signals were observed in the putative ascidian cells in the tunic matrix (Fig. 7). Strong signals were also observed in the tunic epidermis. No hybridization signal was obtained with the control probes.

\section{Infection tests}

The results of the infection tests are summarized in Table 2. Healthy ascidians injected with hemolymph taken from the diseased animals (Expt 1) did not show any signs of the disease. On the other hand, the tunics of all the healthy ascidians which cohabited with affected animals (Expt 2) became softened, and they were considered to be affected by soft tunic syndrome. In the 6 repeated trials in which pieces of softened tunics were immersed in the rearing water (Expt 3), most of the healthy ascidians (97\% in total) used in the experiments were affected by the disease, exhibiting softened, weak tunics. Softening occurred first in the regions of 2 siphons and then spread to other areas of the tunic. Once tunics became softened, the ascidians did not recover and eventually died 3 to $10 \mathrm{~d}$ after the softening of the tunics was noticed. In the 2 infection trials using the tunics of diseased ascidians obtained from previous experiments as the sources of infection (Expt 4), the disease was successfully transmitted to the new healthy animals, which showed softened tunics. In the control groups, no ascidians showed any disease signs and no mortality was observed during the experiments, except for 1 individual, which was found dead without softening of the tunic.

In histological observations of the 5 experimentally diseased ascidians, principally the same histopathological changes were observed as those in the spontaneously affected ascidians. The flagellate-like cells were also found in the tunics of all 5 animals.

\section{Characterization of the infectious agent}

As summarized in Table 3, the tunics of affected animals lost infectivity by freezing at $-80^{\circ} \mathrm{C}$ for $24 \mathrm{~h}$ (Expt 5). The tunics also lost infectivity by homogenization (Expt 6). The presumed infectious agent was able to pass through the $5.0 \mu \mathrm{m}$ membrane filter (Expt 7). On the other hand, it was not detected in the filtrate of $0.45 \mu \mathrm{m}$ filter.

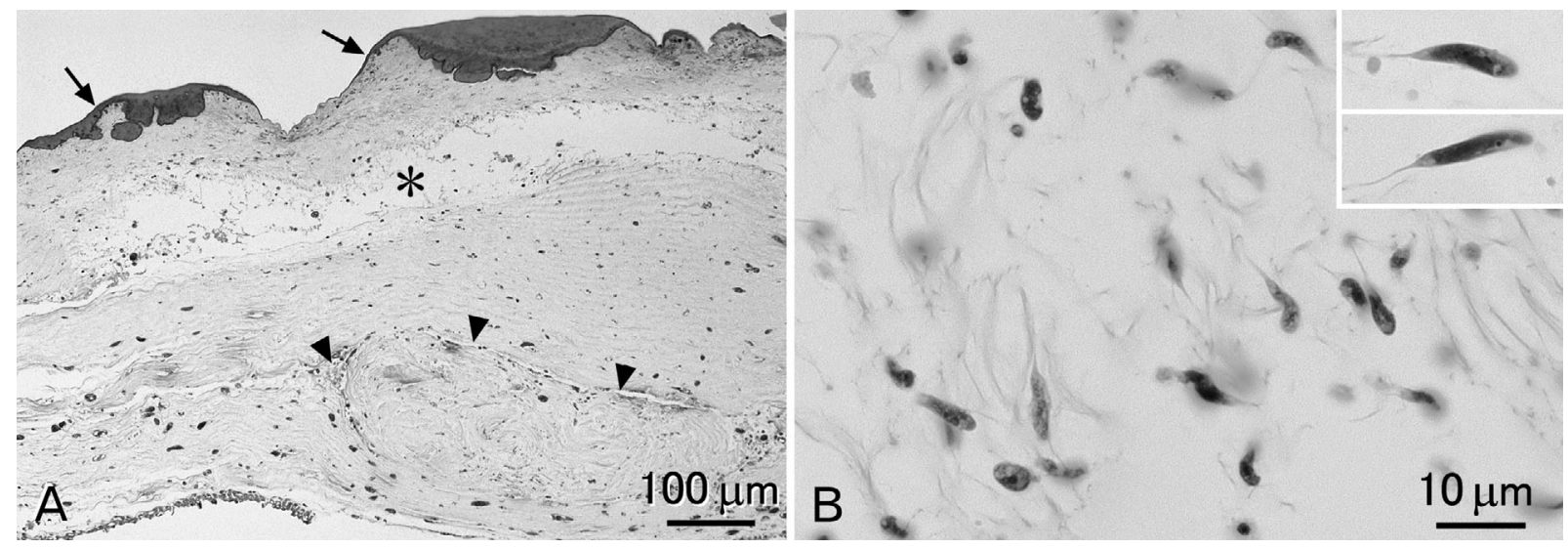

Fig. 6. Halocynthia roretzi. Sections of the tunic of a diseased ascidian sampled in Korea. Hematoxylin and eosin (H\&E) stain. (A) Disintegration of the tunic matrix is apparent. A hollow space $(*)$ and a gap or discontinuity (arrowheads) are observed. Arrows indicate the outer surface of the tunic. (B) Higher magnification showing the flagellate-like cells found in the tunic. Note that the cells have various shapes. Insets show that the cells are fusiform with a flagellum-like structure on one end 

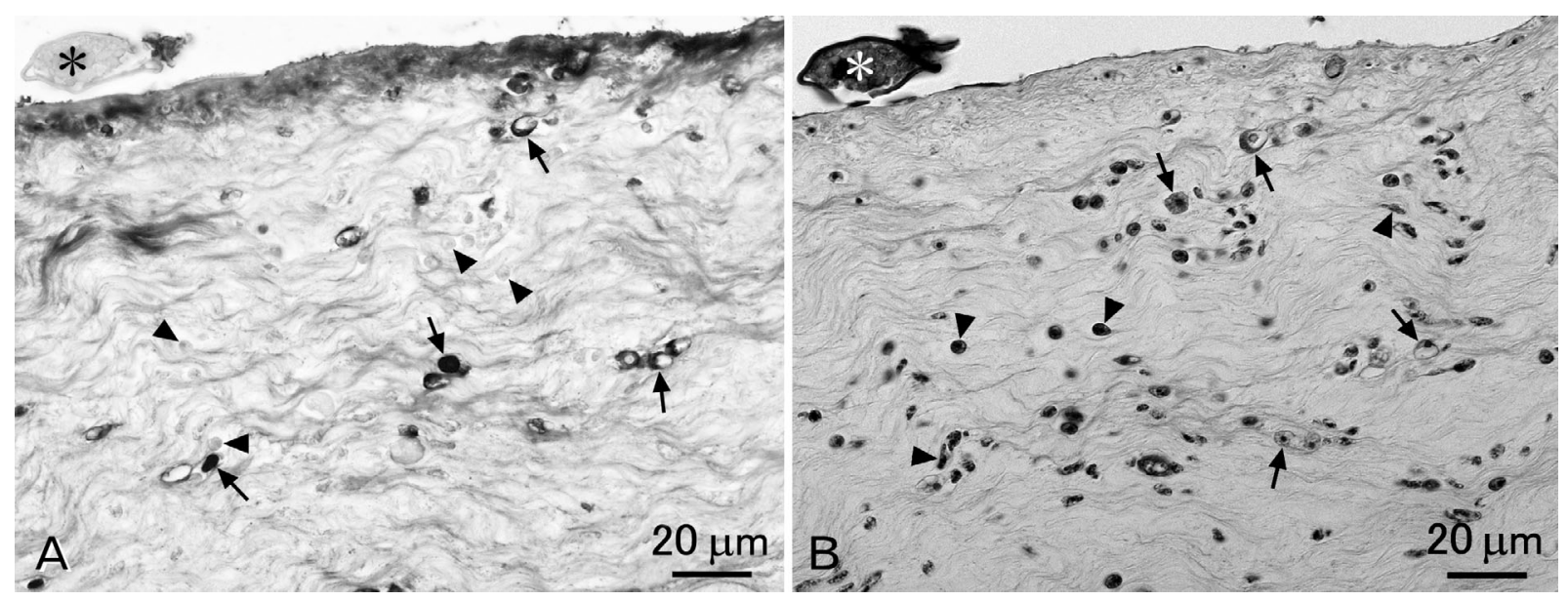

Fig. 7. Halocynthia roretzi. Two almost adjacent histological sections from the same region of the tunic of a diseased ascidian. The sections were cut perpendicularly to the tunic surface. $*$ : protist outside of the tunic. (A) In situ hybridization with probes for $18 \mathrm{~S}$ rRNA of the ascidian. Strong hybridization signals are observed on the presumed ascidian cells (arrows), whereas virtually no signal is obtained on the flagellate-like cells, in which the signal is seen only very faintly (arrowheads). (B) Hematoxylin and eosin (H\&E) staining. The majority of the cells seen in this picture are flagellate-like cells of various shapes. Some of them are indicated by arrowheads. Arrows indicate host cells

Table 2. Halocynthia roretzi. Results of the infection trials. -: No clinical signs observed

\begin{tabular}{|c|c|c|c|c|}
\hline Expt & $\begin{array}{l}\text { Infection source } \\
\text { (Stn and age) }\end{array}$ & $\begin{array}{c}\text { Water } \\
\text { temp. }\left({ }^{\circ} \mathrm{C}\right)\end{array}$ & $\begin{array}{l}\text { Appearance of } \\
\text { clinical signs }(\mathrm{d})^{\mathrm{a}}\end{array}$ & $\begin{array}{l}\text { No. of dead/total } \\
\text { no. of animals }\end{array}$ \\
\hline 1: Hemolymph injection & $\begin{array}{l}\text { Diseased (Stn 5, } 2 \text { yr) } \\
\text { Healthy (Stn 10, } 2 \text { yr) }\end{array}$ & $9-12$ & $\begin{array}{l}- \\
-\end{array}$ & $\begin{array}{l}0 / 5 \\
0 / 5\end{array}$ \\
\hline $\begin{array}{l}\text { 2: Cohabitation with } \\
\text { diseased ascidians }\end{array}$ & $\begin{array}{l}\text { Diseased (Stn 5, } 2 \text { yr) } \\
\text { Healthy (Stn 10, } 2 \text { yr) } \\
\text { Diseased (Stn 5, } 2 \text { yr) } \\
\text { Healthy (Stn 10, } 2 \text { yr) } \\
\text { Diseased (Stn 6, } 2 \text { yr) } \\
\text { Healthy (Stn 12, } 2 \text { yr) }\end{array}$ & $\begin{array}{l}10-17 \\
21-23 \\
10-18\end{array}$ & $\begin{array}{c}12 \\
- \\
22 \\
- \\
16 \\
-\end{array}$ & $\begin{array}{c}12 / 12 \\
0 / 12 \\
11 / 12 \\
0 / 12 \\
12 / 12^{\mathrm{b}}(1)^{\mathrm{c}} \\
1 / 12(1)^{\mathrm{c}}\end{array}$ \\
\hline $\begin{array}{l}\text { 3: Immersion of affected } \\
\text { tunics in the rearing } \\
\text { water }\end{array}$ & $\begin{array}{l}\text { Diseased (Stn 7, } 2 \text { yr) } \\
\text { Healthy (Stn 10,2 yr) } \\
\text { Diseased (Stn 9, } 2 \text { yr) } \\
\text { Healthy (Stn 10,2 yr) } \\
\text { Diseased (Stn 14, } 1 \text { yr) } \\
\text { Healthy (Stn 10,2 yr) } \\
\text { Diseased (Stn 14,2 yr) } \\
\text { Healthy (Stn 10,2 yr) }\end{array}$ & $\begin{array}{l}17-22 \\
13-20 \\
16-23 \\
10-21\end{array}$ & $\begin{array}{c}14 \\
- \\
10 \\
- \\
10 \\
- \\
19 \\
-\end{array}$ & $\begin{array}{c}12 / 12 \\
0 / 12 \\
12 / 12 \\
0 / 12 \\
12 / 12 \\
0 / 12 \\
12 / 12^{\mathrm{d}} \\
0 / 12\end{array}$ \\
\hline $\begin{array}{l}\text { 4: Successive transmission } \\
\text { with experimentally } \\
\text { infected tunics as the } \\
\text { inoculum }\end{array}$ & $\begin{array}{l}\text { Experimentally diseased tunic (A) } \\
\text { Healthy (Stn 10, } 2 \text { yr) } \\
\text { Experimentally diseased tunic (B) } \\
\text { Healthy (Stn 10, } 2 \text { yr) }\end{array}$ & $\begin{array}{l}10-21 \\
15-21\end{array}$ & $\begin{array}{l}16 \\
- \\
27 \\
-\end{array}$ & $\begin{array}{c}12 / 12 \\
0 / 12 \\
12 / 12 \\
0 / 12\end{array}$ \\
\hline
\end{tabular}

\section{DISCUSSION}

The epizootiological investigation showed that the disease tended to spread sequentially from affected individuals to neighboring animals. In addition, the areas where disease outbreaks occurred increased year by year. These observations indicate the possibility that the disease is infectious. The experimental infections in the present study clearly confirmed that the disease is transmissible. The histopathological changes found in spontaneously infected ascidians were reproduced in the experimentally infected ani- 
Table 3. Halocynthia roretzi. Results of characterization of physical properties of the presumed infectious agent

\begin{tabular}{|c|c|c|c|}
\hline Expt & Source of inoculum (Stn and age) & $\begin{array}{c}\text { Water } \\
\text { temp. }\left({ }^{\circ} \mathrm{C}\right)\end{array}$ & $\begin{array}{l}\text { No. of dead/total } \\
\text { no. of animals }\end{array}$ \\
\hline 5: Susceptibility to freezing & $\begin{array}{l}\text { Frozen diseased tunics (Stn 14, } 2 \text { yr) } \\
\text { Fresh diseased tunics } \\
\text { Frozen healthy tunics (Stn 10, } 2 \text { yr) } \\
\text { Fresh healthy tunics }\end{array}$ & $17-22$ & $\begin{array}{c}0 / 12 \\
12 / 12 \\
0 / 12 \\
0 / 12\end{array}$ \\
\hline $\begin{array}{l}\text { 6: Susceptibility to physical } \\
\text { damage }\end{array}$ & $\begin{array}{l}\text { Minced diseased tunics (Stn } 5,2 \mathrm{yr} \text { ) } \\
\text { Pieces of diseased tunics } \\
\text { Minced tunics of healthy ascidians (Stn } 10,2 \mathrm{yr} \text { ) } \\
0.45 \mu \mathrm{m} \text { filtrate } 1^{\mathrm{a}}(\operatorname{Stn} 5,2 \mathrm{yr}) \\
0.45 \mu \mathrm{m} \text { filtrate } 2^{\mathrm{a}} \\
5 \mu \mathrm{m} \text { filtrate } 1^{\mathrm{a}} \\
5 \mu \mathrm{m} \text { filtrate } 2^{\mathrm{a}}\end{array}$ & $17-22$ & $\begin{array}{c}0 / 12 \\
12 / 12 \\
0 / 12 \\
0 / 12 \\
0 / 12 \\
6 / 12 \\
11 / 12\end{array}$ \\
\hline 7: Size & $\begin{array}{l}\text { Seawater without filtering } 1^{\mathrm{a}} \\
\text { Seawater without filtering } 2^{\mathrm{a}} \\
\text { Pieces of diseased tunics } 1 \\
\text { Pieces of diseased tunics } 2 \\
\text { Pieces of healthy tunics (Stn } 10,2 \text { yr) }\end{array}$ & $18-21$ & $\begin{array}{c}11 / 12 \\
12 / 12 \\
10 / 12 \\
10 / 12 \\
0 / 12\end{array}$ \\
\hline
\end{tabular}

mals. Furthermore, the successful transmission of the disease from the softened tunic of the experimentally infected ascidians to other healthy animals strongly suggests that the disease is mediated by a certain biological agent that can multiply in ascidians, and that the disease is not caused by environmental factors such as chemical pollutions. This conclusion is further supported by the fact that the infectivity of the softened tunic can be lost by freezing. The results of the experimental infections also indicate that the causative agent is released from the tunic of an affected animal, becomes waterborne, and infects another ascidian.

Soft tunic syndrome is likely to have been introduced into Japan by the juvenile ascidians imported from Korea. The similarities of the clinical signs and histopathological characteristics, including the presence of the flagellate-like cells, of the diseases in Japan and Korea indicate that the mortalities of the ascidians in both countries are most likely caused by the same disease. Additionally, the epizootiological information revealed that 3 of the 7 farming areas where the outbreaks of the disease occurred in 2007 and 2008 have a previous history of introducing ascidians from Korea in 2004 and/or 2006, and that another 3 of the 7 areas are located in close proximity of the farming sites where the ascidians were imported from Korea. The disease has not been observed at Stn 20 despite the history of the introduction of ascidians from Korea. Stn 20 is the southernmost site of the ascidian culture area and there are only a small number of farming facilities at this site. This low density of farming facilities may have prevented the infectious agent from spreading and settling. There is one epizootiological difference in the disease occurrence between Japan and Korea, however. In Korea, the disease occurs in cultured ascidians of all age groups (Jung et al. 2001), while the affected ascidians in Japan consisted mainly of $2+$ and $3+$ individuals, and a small number of $1+$ but no $0+$ animals have been observed to be affected so far. It is uncertain what causes this difference.

The causative agent seems to have already settled in many ascidian farming areas in Japan. In 2009, the disease had already expanded to areas where the ascidians had not been directly introduced from Korea. The causative agent was probably spread to surrounding areas either by transportation of ascidians or by seawater currents. Moreover, once an outbreak of the disease occurs, it seems likely that the disease repeatedly occurs in the following years in the same place.

The findings of the present study indicate the possibility that a flagellated protist is the causative agent of soft tunic syndrome. The flagellate-like cells were observed only in the tunics of affected ascidians that were thought to be affected with soft tunic syndrome by clinical observations, but never observed in the apparently healthy ascidians or in the animals that were diseased but had rather normal, rigid tunics. Although the flagellate-like cells were not found in the tunics of a small number of affected ascidians, it seems very plausible that the flagellate-like cells were actually present in those animals but the sample pieces of tunics were obtained from portions where these cells were very scarce, because the localization of these cells is very uneven in the tunic tissue samples from individual animals. Moreover, the cells were observed only in 1 of 4 mildly affected ascidians but found in 30 
of 32 animals that had markedly weak tunics. The presence of the flagellate-like cells was also confirmed in the experimentally infected animals.

The results of the infection trials and the physical property tests of the causative agent are consistent with the supposition that the flagellate-like cells are the causative agent of the disease. The healthy ascidians injected with the hemolymph of affected ascidians did not develop the disease. This is reasonable, because the flagellate-like cells were only found in the tunic matrix of the affected animals and were not found in the internal soft tissues. A viral etiology is unlikely, because no infectivity was detected in the homogenized tunic or in the $0.45 \mu \mathrm{m}$ filtrate of the seawater in which the softened tunics were immersed. Moreover, healthy tunic matrix does not contain many cells, which are required for a virus to multiply, and no common cytopathological changes suggestive of viral etiology were observed in the tunic epidermis among affected animals. Hirose et al. (2009) also did not find any morphological changes or virus-like particles in the tunic epidermal cells of affected animals using electron microscopy. Although marine birnavirus was detected in various tissues of the ascidian, there was no correlation between the virus detection and the disease (Azumi et al. 2007a). Bacterial etiology is also unlikely, since pathogenicity of tunics can be lost by mincing with a food processor. In addition, no bacterialike particles were observed in affected ascidians. On the other hand, the physical properties of the causative agent seem to fit those of the flagellate-like cell found in the affected ascidians.

In contrast to the present study, Kitamura et al. (2010) and Hirose et al. (2009) did not find any protistlike cells in the tunics of ascidians affected by soft tunic syndrome. This inconsistency is probably because they observed resin sections of the tissues with transmission electron microscopy or scanning electron microscopy. Since the observable area is very small in those methods compared to that in ordinary histopathology with paraffin sections, it is plausible that the number of flagellate-like cells included in the tissues they sampled was too small; the distribution of the cells is very uneven. It is also likely that the cells were overlooked in their observations for 2 reasons: first, it is difficult to notice the presence of these cells without staining with adequate chemical dyes such as H\&E, and second, the whole cell shape is difficult to observe in very thin sections.

The pathogenesis of the disease should be investigated in future studies. Even if the flagellate-like cells are indeed a flagellate and the causative agent of the disease, it is still difficult to hypothesize a mechanism by which the flagellate causes such damage in the tunics as found in histological observations. Although the presence of the flagellate-like cells and the softened tunics were well correlated at the individual animal level, the flagellate-like cells were not always observed in the lesions where the arrangement of the tunic fibers was markedly disturbed. The disturbances of tunic fiber layers, such as discontinuity of the layers through a large area, seem unlikely to be directly caused by a parasitic organism, but may be better explained by changes in the activity of tunic epidermal cells, which secrete tunic fibers (Kimura \& Itoh 1996). Furthermore, we cannot completely discard the possibility that the flagellate-like cells are a secondary invader and that the true causative agent of the disease is yet to be found.

Choi et al. (2006) identified certain cytoplasmic granules or inclusions found in eosinophilic hemocytes as paramyxean parasites, and suggested a possibility that they are the causative agent of soft tunic syndrome. However, they did not show any evidence to justify their claim that the observed cytoplasmic granules, in which no intracellular organelles were observed in electron microscopy, are parasitic organisms. Similar granular inclusions are found in tunic cells and in hemocytes of healthy ascidians (Ohtake et al. 1994, Hirose et al. 2009). In the present study, the hemocytes that are exactly like 'paramyxean-infected cells' in light microscopy reported by Choi et al. (2006) were also found in the internal organs of all ascidians observed, irrespective of the health condition of the animals. Therefore, these cells are most likely a type of normal hemocyte of the ascidian, possibly the vacuolated cell (Dan-Sohkawa et al. 1995).

Occurrence of the disease was correlated with water temperature; mortalities caused by soft tunic syndrome ceased when the temperature exceeded $20^{\circ} \mathrm{C}$ and started to increase 2 or 3 mo after the water temperature declined to below $20^{\circ} \mathrm{C}$. From mid-August to September, when the temperature lies above $20^{\circ} \mathrm{C}$, the ascidian closes its 2 siphons and does not ingest food. This state is called 'summer dormancy.' This might explain why the disease subsides when the water temperature is high. In the infection tests, softening of tunics occurred first in the regions of the siphons, which seems to suggest that the infectious agent first invades these areas by the water movement through the siphons. Hence, summer dormancy may reduce the possibility of infection by stopping the water movement through the body.

In the present study, we could not present conclusive evidence that the flagellate-like cells are not ascidian cells but a distinct organism. We have not been able to isolate a flagellated protist from the softened tunic. However, circumstantial evidence supports the conclusion that these cells are a protist. ISH revealed that these cells do not contain ascidian 18S rRNA. Although 
it is still possible to argue that the cells are actually a certain type of host cell which has a very small amount of 18S rRNA, this is unlikely because the cytoplasm of the cells are stained rather strongly with hematoxylin, which usually indicates the presence of abundant rRNA. To clarify this point, the cloning of genes from the flagellate-like cells, taxonomic analyses with the cloned gene, and ISH using probes for the cloned gene are required. Such studies would also enable us to diagnose the disease rapidly, with PCR utilizing the genetic data. These are the subjects of our ongoing study. At present, it seems at least certain that the flagellate-like cells are somehow involved in soft tunic syndrome, and the presence of these cells can be used as the criterion for the histopathological diagnosis for the disease.

Acknowledgements. We are grateful to Professor Jung Tae Sung (Gyeongsang National University) for providing samples and important information. We are indebted to Professor Euichi Hirose (University of the Ryukyus) who kindly reviewed the manuscript. This study was supported by a grant from the Ministry of Agriculture, Forestry, and Fisheries of Japan.

\section{LITERATURE CITED}

Azumi K, Nakamura S, Kitamura S, Jung SJ and others (2007a) Accumulation of organotin compounds and marine birnavirus detection in Korean ascidians. Fish Sci 73:263-269

Azumi K, Usami T, Kamimura A, Sabau SV and others (2007b) cDNA microarray analyses reveal candidate marker genes for the detection of ascidian disease in Korea. Zool Sci 24:1231-1240

Bell TA, Lightner DV (1988) A handbook of normal penaeid shrimp histology. Allen Press, Lawrence, KS

Editorial responsibility: Eugene Burreson, Gloucester Point, Virginia, USA
Choi DL, Jee BY, Choi HJ, Hwang JY, Kim JW, Berthe FCJ (2006) First report on histology and ultrastructure of an intrahemocytic paramyxean parasite (IPP) from tunicate Halocynthia roretzi in Korea. Dis Aquat Org 72:65-69

Dan-Sohkawa M, Morimoto M, Mishima H, Kaneko H (1995) Characterization of coelomocytes of the ascidian Halocynthia roretzi based on phase-contrast, time-lapse video and scanning electron microscopic observations. Zool Sci 12: 289-301

- Hirose E, Ohtake S, Azumi K (2009) Morphological characterization of the tunic in the edible ascidian Halocynthia roretzi (Drasche), with remarks on 'soft tunic syndrome' in aquaculture. J Fish Dis 32:433-445

Hur YB, Park JH, Han HK, Choi HS, Kyun MK, Yun HD (2006) Mass mortality of the cultured sea squirts Halocynthia roretzi in Korea. Abstracts of International Workshop on Summer Mortality of Marine Shellfish, Busan. Pusan National University, Busan, p 41

Jung SJ, Oh MJ, Date T, Suzuki S (2001) Isolation of marine birnavirus from sea squirts Halocynthia roretzi. In: Sawada H, Yokosawa H, Lambert CC (eds) The biology of ascidians. Springer-Verlag, Tokyo, p 436-441

Kimura S, Itoh T (1996) New cellulose synthesizing complexes (terminal complexes) involved in animal cellulose biosynthesis in the tunicate Metandrocarpa uedai. Protoplasma 194:151-163

Kitamura S, Ohtake S, Song JY, Jung SJ and others (2010) Tunic morphology and viral surveillance in diseased Korean ascidians: soft tunic syndrome in the edible ascidian, Halocynthia roretzi (Drasche), in aquaculture. J Fish Dis 33:153-160

Miwa S, Kamaishi T (2009) X-cells in pseudotumors of yellowfin goby Acanthogobius flavimanus: a protistan organism distinct from that in flathead flounder Hippoglossoides dubius. Dis Aquat Org 85:53-57

Miwa S, Nakayasu C, Kamaishi T, Yoshiura Y (2004) X-cells in fish pseudotumors are parasitic protozoans. Dis Aquat Org 58:165-170

Ohtake S, Abe T, Shishikura F, Tanaka K (1994) The phagocytes in hemolymph of Halocynthia roretzi and their phagocytic activity. Zool Sci 11:681-691

Submitted: January 20, 2010; Accepted: April 12, 2010 Proofs received from author(s): June 9, 2010 